\title{
Impact of Wood Moisture in Charcoal Production and Quality
}

\author{
Wagner Davel Canal ${ }^{1}$ (1) 0000-0003-3651-6204 \\ Ana Márcia Macedo Carvalho ${ }^{1}$ (1) 0000-0002-5883-8987 \\ Clarissa Gusmão Figueiró ${ }^{1}$ (1) 0000-0002-8572-554X \\ Angélica de Cássia Oliveira Carneiro ${ }^{1}$ (1) 0000-0002-5992-3059 \\ Lucas de Freitas Fialho ${ }^{1}$ (D) 0000-0001-8002-9214 \\ Danilo Barros Donato ${ }^{1}$ (1) 0000-0002-7605-9039
}

\begin{abstract}
The charcoal production when performed in woods with high moisture content negatively impacts the pyrolysis and causes an increase of greenhouse emissions. The aim of this study was to investigate the effects of moisture on the production and quality of charcoal for the pig iron industry. The slow pyrolysis of Eucalyptus sp. was carried out in four different wood moistures, $0,20,40$ and $60 \%$ (dry base). The charcoal and gas yield decreased according to the increase of wood moisture. On the other hand, the bio-oil yield and charcoal friability increased along with the moisture content. The proximate analysis, bulk density and higher heating value of the charcoal were not influenced by the moisture content. The use of wood with moisture content below $20 \%$ in the production of charcoal is an alternative to improve productivity, contributing for the economic sustanainability of this sector.
\end{abstract}

Keywords: pyrolysis, friability, yield.

\section{INTRODUCTION AND OBJECTIVES}

Independence from fossil fuels, supported by environmental agencies and non-governmental organizations, contributes to emphasize biomass in the energy scenario. Biomass offers a unique advantage for the environment since it is characterized as "neutral carbon." In other words, the carbon emitted during the use of biomass was taken off the environment during its development cycle (Saidur el al., 2011).

Raw biomass usually has low energetic density, which causes it to lose competitiveness with fossil fuels (Sosa et al., 2015). To reduce this characteristic, the thermochemical conversion of biomass can be a viable alternative. Slow pyrolysis of biomass is the process in which heat is applied to the material, under the inert atmosphere with a low temperature $\left(300\right.$ to $500^{\circ} \mathrm{C}$ ), resulting in the conversion of this material into a more efficient fuel. This process produces charcoal, a solid material rich in carbon and a volatile portion consisting of non-condensable gasses and condensable organic vapors (Pereira et al., 2013; Shen et al., 2010; Ucar \& Ozkan, 2008).
Brazil is recognized as a major producer and consumer of charcoal. In this country, the main charcoal production is for supplying the pig iron and steel manufacturing sectors (EPE, 2015). Of the total of trees planted in Brazil in 2016, $14 \%$ belongs to the charcoal ironmaster industry (IBA, 2017). Eucalyptus is the most commonly used tree genotype for charcoal production. The climate and soil conditions, with the vast investment in research of this species, favored its high quality and productivity (Silva et al., 2018; Vital et al., 2013; Welfle, 2017).

Several factors may negatively influence pyrolysis in big furnaces. One of the greatest causes of damage to this production in Brazil is the moisture content of wood (Zanuncio et al., 2014). In the environmental aspect, higher moisture content in the biomass contributes to generate harmful products to the environment and human health (Canal et al., 2016). In the beginning of the pyrolysis, characterized by the evaporation of water, an intense production of soot and toxic by-products occurs (Yang et al., 2007). If the wood presents more moisture content than adequate, the tendency is the release of such noxious components to increase the pyrolysis.

${ }^{1}$ Universidade Federal de Viçosa (UFV), Viçosa, MG, Brasil 
In the productive perspective, the high moisture content of the wood causes instability in the average maximum temperature of pyrolysis, and increases ignition and process times (Arruda et al., 2011). Furthermore, the carbonization of wood with such characteristics slows the furnace heating rate. The moisture evaporation rate depends on the heating rate of the pyrolysis, if this process is carried out with a low heating rate, the wood external surface degradation occurs, while water evaporation is still under way in the internal zones (Di Blasi et al., 2016). These simultaneous reactions can cause an increase in the pressure inside the cells, thus causing a rupture of the parenchyma cells of wood (Zeng et al., 2017). Therefore, the physical and mechanical properties of the wood in process are also affected, impairing the charcoal properties (Missio et al., 2013).

The changes caused in the pyrolysis from the use of wood with high moisture content directly interfere in the process control, which makes it difficult to standardize the production and quality of charcoal. The objective of this study is to investigate the impacts of wood moisture on the production and quality of charcoal to the pig iron industry.

\section{MATERIALS AND METHODS}

\subsection{Materials}

One clone of Eucalyptus sp. from a clonal test located in Divinésia (Minas Gerais) was used. The planting was conducted with $3 \times 3$ meters spacing, and the trees were harvested at the age of 7 years. A total of 3 trees, representative of the population, were used as sample. The selection was made based on the quadratic diameter of the plantation. The wood used in this study presented $26.47 \%$ of lignin, $3.06 \%$ of extractives and 70.47 of holocelluloses, $23.48 \mathrm{MJ} \cdot \mathrm{Kg}^{-1}$ of high heating value (HHV), and $0.48 \mathrm{~g} . \mathrm{cm}^{-3}$ for bulk density.

Transversal sections were collected of each tree, corresponding to the base (0\%), 25, 50, 75 and $100 \%$ of its height, up to a diameter of 6 centimeters. A composite sample was formed from the collected discs. To obtain the samples with different moisture content $(0 \%, 20 \%, 40 \%$ and $60 \%)$, they were conditioned in the open air so its fractions could reach $20 \%, 40 \%$ and $60 \%$ moisture (d.b.). A forced air circulation oven $\left(103 \pm 2{ }^{\circ} \mathrm{C}\right)$ was used to obtain $0 \%$ moisture in the samples.

\subsection{Pyrolisis procedure}

Pyrolysis experiments were carried out in an electric laboratory oven using approximately $290 \mathrm{~g}$ of wood. Samples were inserted in a metallic cylindrical container made of stainless steel with $0.003 \mathrm{~m}^{3}$ approximately. The initial temperature was $100{ }^{\circ} \mathrm{C}$, and the final temperature was $450{ }^{\circ} \mathrm{C}$, remaining stable in the last 60 minutes; therefore, the pyrolysis time was $4.5 \mathrm{~h}$, which corresponds to an average heating rate of $1.67^{\circ} \mathrm{C} \mathrm{min}$.

These experimental conditions were defined as reported by Pereira et al. (2012). According to these authors, the final carbonization temperatures (close to $450^{\circ} \mathrm{C}$ ) provides a desirable balance between the gravimetric yield and the carbon content fixed in the charcoal, especially when the destination is for steel.

The liquid products were condensed in a water condenser trap, collected from flaks and weighed, and the bio-oil yield was calculated with Equation 1. The charcoal collected in the reactor was weighed and the charcoal yield was calculated with Equation 2. The yield of produced gas was measured by difference of weight percent (Equation 3).

$$
\begin{aligned}
& \text { Charcoal yield }(\%)=\frac{\text { charcoal weight }(\mathrm{g})}{\text { wood weight }(\mathrm{g})} \\
& \text { Bio - oil yield }(\%)=\frac{\text { bio }- \text { oil weight }(\mathrm{g})}{\text { wood weight }(\mathrm{g})}
\end{aligned}
$$

$$
\text { Gas yield }(\%)=10-(\text { charcoal yield }(\%))-(\text { boi }- \text { oil yield }(\%))
$$

\subsection{Charcoal characterization}

A portion of the charcoal produced, for each treatment, were used to determine density and friability. The remaining samples were milled manually and sieved. Samples that fit the sieves with granulometry between 40 and 60 mesh were selected to determine the content of volatile matter, fixed carbon, ash, and higher heating value.

Approximately $20 \mathrm{~g}$ of charcoal were selected randomly and weighed. Then, the samples were rotated at $35 \mathrm{rpm}$ for 15 minutes in an electronic friabilator (MA-791). The charcoal were dedusted and weighed. The percentage of weight loss was calculated with Equation 4.

$$
\text { Fribility }(\%)=\frac{\text { initial weight }- \text { final weight }}{\text { initial weight }}
$$

The bulk density was determined by the hydrostatic method, in which the samples were immersed in mercury. The proximate analysis of charcoal were determined according to ASTM D3175-89a and ASTM D3174-04 (ASTM, 2009, 2013). Fixed carbon content was calculated by weight percentage 
difference. The higher heating value (HHV) was measured with an adiabatic calorimeter bomb (model IKA300).

Fixed carbon yield (\%) was performed to investigate the efficiency of the process using Equation 5.

$$
\begin{gathered}
\begin{array}{c}
\text { Fixed carbon yield }(\%)= \\
\text { charcoal yield }(\%) \times(100-\operatorname{volatil} \text { matter }(\%)-\operatorname{charcoal} \text { ash }(\%))
\end{array} \\
100-\operatorname{wood} \sinh (\%)
\end{gathered}
$$

Energy yield (\%) is defined as the portion of energy contained in the biomass that is recovered in the charcoal (Equation 6).

$$
\text { Energy yield }(\%)=\frac{\text { charcoal yield }(\%) \times \mathrm{HHV}_{\text {charcoal }}}{\mathrm{HHV}_{\text {wood }}}
$$

Where $\mathrm{HHV}_{\text {charcoal }}$ higher heating values of charcoal $(\mathrm{MJ} / \mathrm{kg}) ; \mathrm{HHV}_{\text {wood }}$ : higher heating value of biomass $(\mathrm{MJ} / \mathrm{kg})$.

\subsection{Data analysis}

The experiment was carried out according to a randomized design with 4 treatments (wood moisture) with three replicates (tree-sample), giving a total of 12 sampling units. Data normality was verified by Lilliefors test and homogeneity of variance by Hartley, Cochran, and Bartlett; these assumptions were fulfilled.

The verification of the effect of wood moisture content on yields and charcoal properties was carried out using the
F-test of ANOVA at a 5\% probability. For the properties that did not present the effect of moisture, a graphic descriptive analysis was performed showing the mean and standard deviation of each property.

For the positive results of the moisture content effect the linear model $\left(Y=\beta_{0}+\beta_{1} X+\varepsilon\right)$ was adjusted using $\mathrm{R}$ software ( $\mathrm{R}$ Core Team, 2017). To verify the significance of the parameters of the adjusted equation, the Student's t-test was performed. The criteria used to determine the quality of fit of the model to the experimental data were residual standard error and coefficient of determination $\left(\mathrm{R}^{2}\right)$.

\section{RESULTS AND DISCUSSION}

The moisture content influences charcoal and bio-oil. However, the effect of moisture on the gas yield was not observed. The linear model used in this study presented precision measurements, confirming the good fit of the equations, and it is therefore indicated for the comprehension of the moisture effect in wood pyrolysis (Table 1).

The sign of the parameters in the independent variables indicates the effect of this variable on the dependent variable, showing there was a negative effect of wood moisture content on charcoal. However, for the bio-oil yield there was a positive effect with the increase of the moisture content. The charcoal yield decreased $41.6 \%$ as the moisture content of the wood increases. Therefore, bio-oil yield increased $37.6 \%$ as moisture content

\begin{tabular}{|c|c|c|c|c|c|c|}
\hline Property & Parameters & $\begin{array}{l}\text { Estimation of } \\
\text { parameters }\end{array}$ & p-value & Regression & $\begin{array}{c}\text { Residual } \\
\text { standard } \\
\text { error }\end{array}$ & $\mathbf{R}^{2}$ \\
\hline \multirow{2}{*}{ Charcoal yield } & $\beta_{0}$ & 31.47 & $<0.01^{\star}$ & \multirow{2}{*}{$y=31.47-0.23 x$} & \multirow{2}{*}{1.36} & \multirow{2}{*}{94.39} \\
\hline & $\beta_{1}$ & -0.23 & $<0.01^{*}$ & & & \\
\hline \multirow[b]{2}{*}{ Bio-oil yield } & $\beta_{0}$ & 50.34 & $<0.01^{\star}$ & \multirow[b]{2}{*}{$y=50.34+0.32 x$} & \multirow[b]{2}{*}{1.55} & \multirow[b]{2}{*}{96.14} \\
\hline & $\beta_{1}$ & 0.32 & $<0.01^{*}$ & & & \\
\hline \multirow{2}{*}{ Gas yield } & $\beta_{0}$ & 18.20 & $<0.01^{\star}$ & \multirow{2}{*}{$y=18.20-0.09 x$} & \multirow{2}{*}{0.91} & \multirow{2}{*}{84.99} \\
\hline & $\beta_{1}$ & -0.09 & $<0.20$ & & & \\
\hline
\end{tabular}
increases (Figure 1).

Table 1. Adjusted equations, significance of the parameters and measures of precision of the pyrolysis products yields.

*Significant of $1 \%$ of probability by Student's t-test. 


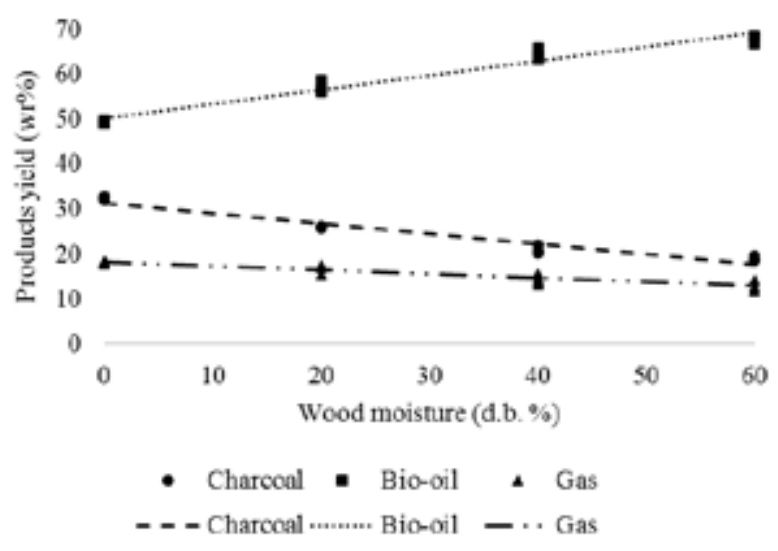

Figure 1. Products of pyrolysis at different moisture contents.

In wood pyrolysis, it is desirable to obtain a high charcoal yield. This parameter was a result of, among other factors, a better use of wood in the pyrolysis furnaces and, consequently, higher energy yield. The higher moisture content can culminate in greater consumption of wood to generate thermal energy to remove water from the pyrolysis system. This high consumption of wood reduces the amount of wood available to be converted into charcoal by pyrolysis. This means that the yield on this product is reduced.

The formation and consumption of liquid rates occurred in steps. The first is characterized by depolymerization of

the wood in the primary tar in the material. In the second step, the primary tar and volatiles are released. In the last step, we have secondary reactions between primary tar in the materials and reactor along the scape.

The increase of moisture content of the wood contributed to a more efficient dissolution of primary tar that results in the major production of bio-oil. The physical behavior of bio-oil was influenced by moisture content of wood. The bio-oil produced with wood with higher moisture content, evaluated through qualitative observations, is a liquid with lower viscosity (Gray et al., 1985).

The increase of moisture content did not influence the gas yield. The effect of moisture content in gas yield is observed at elevated temperatures. In lowest temperatures of pyrolysis occur the weak coupling between moisture evaporation and material pyrolysis (Di Blasi et al., 2000).

The volatile matter, fixed carbon, ash content, bulk density and the higher heating value of the charcoal were statistically equal under different moisture content (Figure 2). In the process of thermal degradation of woody material, some of the wood was removed as volatile materials, resulting from degradation reactions of the hemicelluloses and a portion of the extractives, concentrating fixed carbon and ashes in the final product (Koppejan et al., 2012; Van der Stelt et al., 2011).
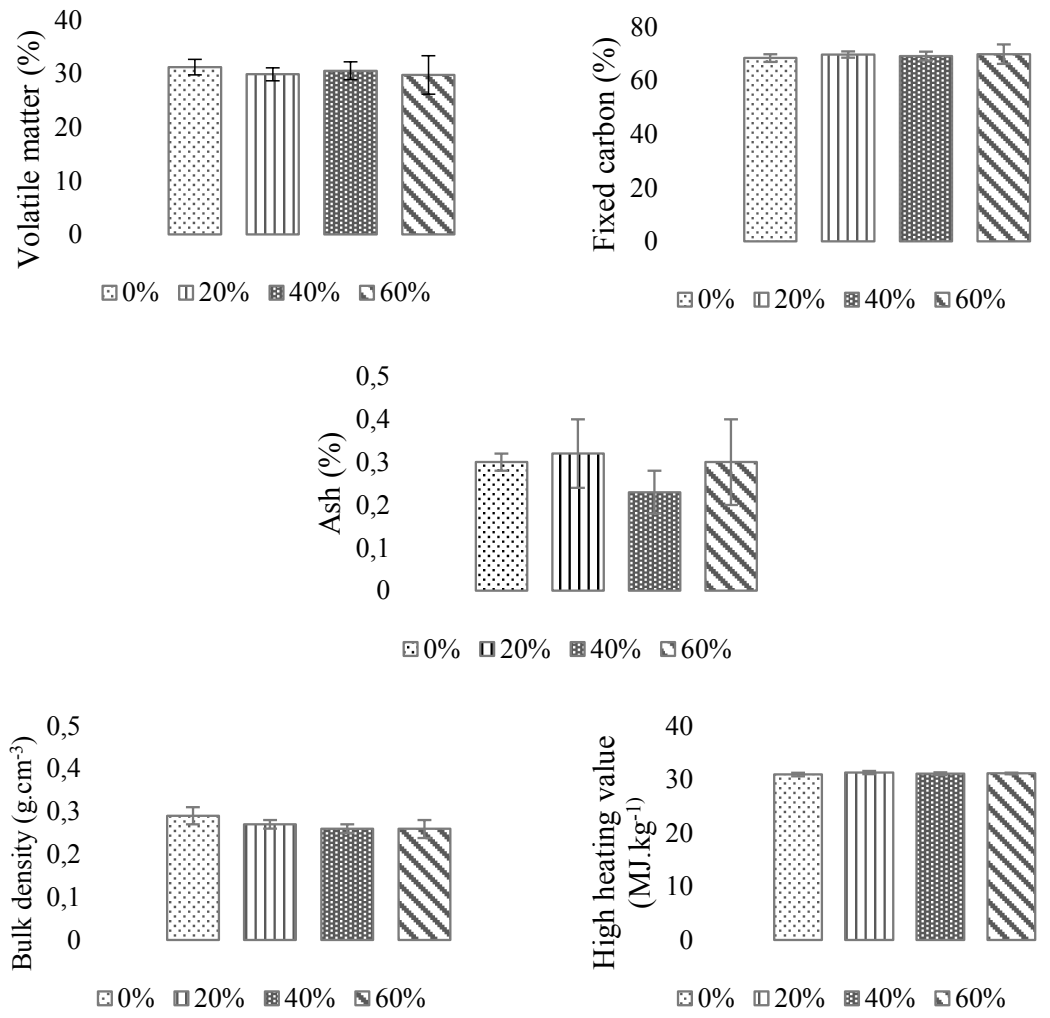

Figure 2. Charcoal properties at $0,20,40$, and $60 \%$ of moisture content.

*Bars indicate standard deviation. 
To the pig iron and steel manufacturing sectors is desirable that the charcoal has some of its proprieties in a specified range. Three of the most important proprieties for these industries are the fixed carbon, ash, and bulk density. For these proprieties is desirable 70 to 80 (wt.\%), less than 5 (wt.\%) and more than $0.22\left(\mathrm{~g} . \mathrm{cm}^{-3}\right)$, respectively (Souza et al., 2016). Since the purpose in this study is directly related to these industries, no differences were expected in these charcoal properties.

When charcoal is produced to the pig iron industry, according to Souza et al. (2016), it is desirable that it has some specific physico-chemical characteristics. Figure 2 shows all treatments met these demands. However, a significant reduce in charcoal yield was the cost to achieve these specific characteristics.

Charcoal friability, energy yield and fixed carbon yield results are summarized in Table 2 and Figure 3. All the parameters in the independent variables indicates a statistically significant effect of the wood moisture in these properties.

As show on Table 2, there is a positive effect of the wood moisture content on the charcoal friability. Moreover, there is a negative effect of the moisture content in the energy and fixed carbon yield. Friability increased $39.6 \%$; on the other hand, energy yield and fixed carbon yield decreased $41.1 \%$ and $40.2 \%$, respectively (Figure 3 ).

Table 2. Adjusted equations, significance of the parameters and measures of precision of the charcoal friability, energy yield and fixed carbon yield.

\begin{tabular}{|c|c|c|c|c|c|c|}
\hline Property & Parameters & $\begin{array}{l}\text { Estimation of } \\
\text { parameters }\end{array}$ & p-value & Regression & $\begin{array}{c}\text { Residual } \\
\text { standard error }\end{array}$ & $\mathbf{R}^{2}$ \\
\hline \multirow{3}{*}{ Friability } & $\beta_{0}$ & 6.46 & $<0.01^{\star}$ & \multirow{3}{*}{$y=6.46+0.05 x$} & \multirow{3}{*}{0.43} & \multirow{3}{*}{87.56} \\
\hline & & & & & & \\
\hline & $\beta_{1}$ & 0.05 & $<0.01^{\star}$ & & & \\
\hline \multirow{3}{*}{ Energy yield } & $\beta_{0}$ & 51.83 & $<0.01^{*}$ & \multirow{3}{*}{$y=51.83-0.37 x$} & \multirow{3}{*}{2.17} & \multirow{3}{*}{94.07} \\
\hline & & & & & & \\
\hline & $\beta_{1}$ & -0.37 & $<0.01^{\star}$ & & & \\
\hline \multirow{3}{*}{ Fixed carbon yield } & $\beta_{0}$ & 21.61 & $<0.01^{\star}$ & \multirow{3}{*}{$y=21.61-0.15 x$} & \multirow{3}{*}{1.04} & \multirow{3}{*}{92.82} \\
\hline & & & & & & \\
\hline & $\beta_{1}$ & -0.15 & $<0.01^{*}$ & & & \\
\hline
\end{tabular}

*Significant of $1 \%$ of probability by Student's t-test.
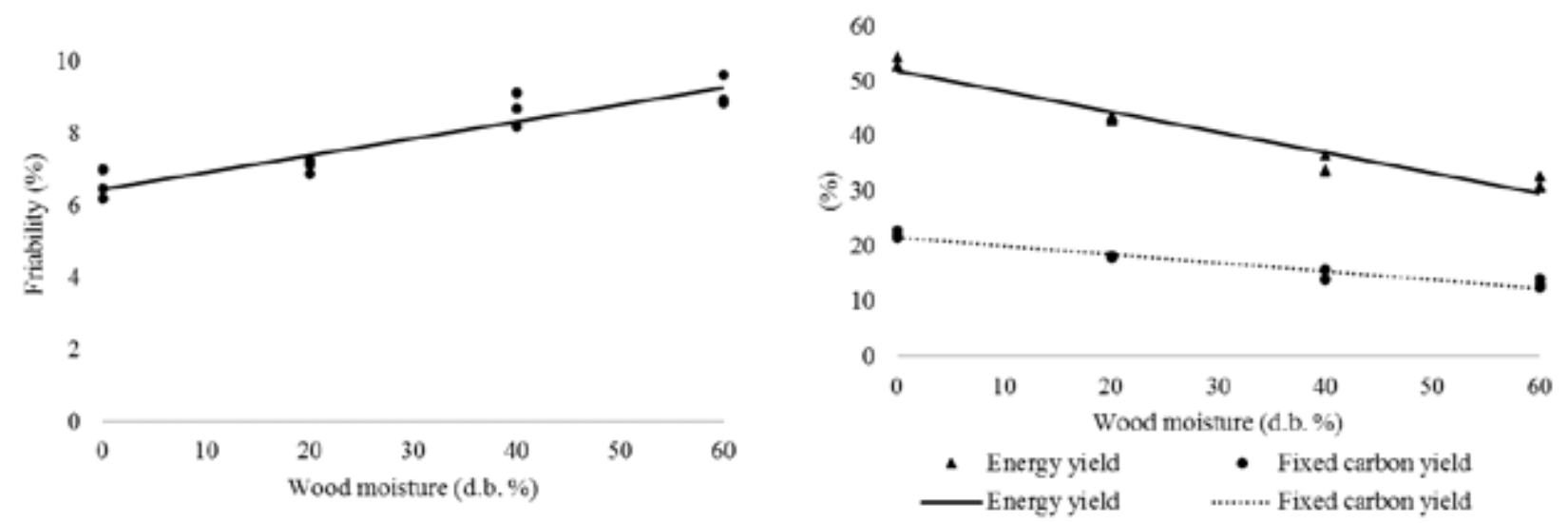

Figure 3. Charcoal friability, energy yield and fixed carbon yield at different moisture contents. 
The high friability of charcoal can limit important processes, such as transportation, handling, and disposal in blast furnaces (Zainuddin et al., 2014). In general, a higher moisture content of the wood can modify physical properties of the charcoal. The high vapor pressure generated inside the wood during the drying pyrolysis can cause internal cracks and breaks along the charcoal, reducing its mechanical resistance.

The increases in the moisture content of the wood caused a drop of $41.1 \%$ and $40.2 \%$ in the energy and fixed carbon yield, respectively. The decrease in these parameters was a consequence of the high consumption of wood to remove water from the pyrolysis system, resulting in a lower charcoal yield, decreasing, therefore, the energy and fixed carbon yield. This fact may generate economic losses for the sector, prejudicing the economic sustainability of the process.

When charcoal is produced to meet the demands of the pig iron industries it is desirable that it be homogeneous and have pre-established physico-chemical properties. Therefore, the charcoal producer seeks, in most cases, to comply with such requirements established by consumers. However, due to an absence of available raw material with adequate moisture content or a high demand from consumers, charcoal production is carried out with materials with high moisture content. In this context, the moisture content of the raw material can influence mainly the yield on products (charcoal, bio-oil, energy and fixed carbon) and the friability of charcoal.

The energy used in pyrolysis, in its endothermic phase, comes from the burning of part of the wood, so the higher energy consumption means a smaller portion of the wood available to be converted into charcoal. Regarding friability, during pyrolysis, a greater amount of water vapor produced can cause the parenchyma cells to rupture, thus increasing such property.

\section{CONCLUSIONS}

The increase of wood moisture $0 \%$ to $60 \%$ (d.b.) decrease the charcoal yield and increase the bio-oil and gas yield. On the other hand, proximate analysis, higher heating value and bulk density of the charcoal was not influenced by the moisture content.

According to the results it is recommended to use wood with moisture content below $20 \%$ (dry basis). In this range there is higher charcoal, energy and fixed carbon yield, and lower friability.

The utilization of wood with low moisture content in the industrial production of charcoal represents an alternative to improve productivity, contributing for economic sustainability of this sector.

\section{ACKNOWLEDGEMENTS}

To the Fundação de Amparo à Pesquisa do Estado de Minas Gerais (FAPEMIG), the Conselho Nacional de Pesquisa e Desenvolvimento (CNPq), the Empresa Brasileira de Pesquisa Agropecuária (Embrapa Florestas), to the Programa das Nações Unidas para o Desenvolvimento (PNUD) and the Thematic Group of Charcoal "G6”.

\section{SUBMISSION STATUS}

Received: 4 Oct. 2017

Accepted: 8 Aug. 2018

Associate editor: Carlos Roberto Sette Jr.

0000-0002-1007-2345

\section{CORRESPONDENCE TO}

\section{Clarissa Gusmão Figueiró}

Universidade Federal de Viçosa (UFV), Av. Peter Henry Rolfs, s/n, Campus Universitário, CEP 36570-900, Viçosa, MG, Brasil

e-mail: clarissagfigueiro@gmail.com

\section{REFERENCES}

American Society for Testing and Materials - ASTM. ASTM D D3175: standard test method for volatile matter in the analysis sample of Coal and Coke. West Conshohocken: ASTM; 2009.

American Society for Testing and Materials - ASTM. ASTM D3174: standard test method for ash in the analysis sample of Coal and Coke from coal. West Conshohocken: ASTM; 2013.

Arruda TPM, Pimenta AS, Vital BR, Lucia RMD, Acosta FC. Avaliação de duas rotinas de carbonização em fornos retangulares. Revista Árvore 2011; 35(4): 949-955. 10.1590/S0100-67622011000500020

Canal WD, Carvalho AMML, Carneiro ACO, Pereira BLC, Donato DB. Efeito do teor de umidade da madeira na emissão de gases de efeito estufa no processo de carbonização. Scientia Florestalis 2016; 44(112): 831-840. 10.18671/scifor.v44n112.05

Di Blasi C, Galgano A, Branca C, Clemente M. Analysis of the interactions between moisture evaporation and exothermic pyrolysis of Hazelnut Shells. Energy \& Fuel 2016; 30(10): 7878-7886. 10.1021/acs.energyfuels.6b00856

Di Blasi C, Gonzalez Hernandez E, Santoro A. Radiative pyrolysis of single moist wood particles. Industrial \& Engineering Chemistry Research 2000; 39(4): 873-882. 10.1021/ie990720i

Empresa de Pesquisa Energética - EPE. Balanço energético nacional 2015: ano base 2014. Rio de Janeiro: EPE; 2015.

Gray MR, Corcoran WH, Gavalas GR. Pyrolysis of a woodderived material: effects of moisture and ash content. Industrial \& Engineering Chemistry Process Design and Development 1985; 24(3): 646-651. 10.1021/i200030a020

Indústria Brasileira de Árvores - IBA. Anuário estatístico 2017: ano base 2016. Brasília, DF: IBA; 2017. 
Koppejan J, Sokhansanj S, Melin S, Madrali S. IEA bioenergy task 32 report: final report: status overview of torrefaction technologies. Paris: IEA; 2012.

Missio LA, Mattos BD, Gatto DA, Lima EA. Thermal analysis of charcoal from fast-growing eucalypt wood: influence of raw material moisture content. Journal of Wood Chemistry and Technology 2013; 34(3): 191-201. 10.1080/02773813.2013.852588

Pereira BLC, Carneiro ACO, Carvalho AMML, Colodette JL, Oliveira AC, Fontes MPF. Influence of chemical composition of eucalyptus wood on gravimetric yield and charcoal properties. Bioresources 2013; 8(3): 4574-4592. 10.15376/biores.8.3.4574-4592

Pereira BLC, Oliveira AC, Carvalho AML, Carneiro ACO, Santos LCS, Vital BR. Quality of wood and charcoal from Eucalyptus clones for ironmaster use. International Journal of Forestry Research 2012; 2012: 523025. 10.1155/2012/523025

Saidur R, Abdelaziz EA, Demirbas A, Hossain MS, Mekhilef S. A review on biomass as a fuel for boilers. Renewable and Sustainable Energy Reviews 2011; 15(5): 2262-2289. 10.1016/j.rser.2011.02.015

Shen DK, Gu S, Bridgwater AV. The thermal performance of the polysaccharides extracted from hardwood: cellulose and hemicellulose. Carbohydrate Polymers 2010; 82(1): 39-45. 10.1016/j.carbpol.2010.04.018

Silva CMS, Carneiro ACO, Vital BR, Figueiró CG, Fialho LF, Magalhães MA et al. Biomass torrefaction for energy purposes: definitions and an overview of challenges and opportunities in Brazil. Renewable and Sustainable Energy Reviews 2018; 82(Pt.3): 2426-2432. 10.1016/j.rser.2017.08.095

Sosa A, Acuna M, McDonnell K, Devlin G. Managing the moisture content of wood biomass for the optimisation of Ireland's transport supply strategy to bioenergy markets and competing industries. Energy 2015; 86: 354-68. 10.1016/j.energy.2015.04.032

Souza ND, Amodei JB, Xavier CN, Dias AF Jr, Carvalho AM. Estudo de caso de uma planta de carbonização: avaliação de características e qualidade do carvão vegetal visando uso siderúrgico. Floresta e Ambiente 2016; 23(2): 270-277. 10.1590/2179-8087.106114

$\mathrm{R}$ Core Team. R: a language and environment for statistical computing [Internet]. Vienna: The R Foundation for Statistical Computing; 2017 [cited 2018 Feb. 24]. Available from: http://www.R-project.org/

Ucar S, Ozkan AR. Characterization of products from the pyrolysis of rapeseed oil cake. Bioresource Technology 2008; 99(18): 8771-8776. 10.1016/j.biortech.2008.04.040

Van der Stelt MJC, Gerhauser H, Kiel JHA, Ptasinski KJ. Biomass upgrading by torrefaction for the production of biofuels: a review. Biomass and Bioenergy 2011; 35(9): 3748-3762. 10.1016/j.biombioe.2011.06.023

Vital BR, Carneiro ACO, Pereira BLC. Qualidade da madeira para fins energéticos. In: Santos F, Colodette J, Queiroz JH, editors. Bioenergia \& biorrefinaria: cana-de-açúcar \& espécies florestais. Viçosa: UFV; 2013. p. 321-354.

Welfle A. Balancing growing global bioenergy resource demands: Brazil's biomass potential and the availability of resource for trade. Biomass and Bioenergy 2017; 105: 83-95. 10.1016/j.biombioe.2017.06.011

Yang H, Yan R, Chen H, Lee DH, Zheng C. Characteristics of hemicellulose, cellulose and lignin pyrolysis. Fuel 2007; 86(12-13): 1781-1788. 10.1016/j.fuel.2006.12.013

Zainuddin MF, Rosnah S, Noriznan MM, Dahlan I. Effect of moisture content on physical properties of animal feed pellets from pineapple plant waste. Agriculture and Agricultural Science Procedia 2014; 2: 224-230. 10.1016/j.aaspro.2014.11.032

Zanuncio AJV, Lima JT, Monteiro TC, Trugilho PF, Lima FS. Secagem ao ar livre da madeira para produção de carvão vegetal. Floresta e Ambiente 2014; 21(3): 401-408. 10.1590/2179-8087.028713

Zeng K, Gauthier D, Li R, Flamant G. Combined effects of initial water content and heating parameters on solar pyrolysis of beech wood. Energy 2017; 125: 552-561. 10.1016/j.energy.2017.02.173 